\title{
The AEW Project: Professional Development for Teacher Aides in Remote Indigenous Communities
}

\author{
Ian Mackie $^{1}$, Bradly Shipway ${ }^{2}$, Ric Dutton $^{3}$, Gary MacLennan $^{4}$ \\ ${ }^{1}$ Doctoral Student SCU Australia; CEO Austeur Enterprises, Australia. \\ ${ }^{2}$ Senior Lecturer SCU, Australia. \\ ${ }^{3}$ Consultant Austeur Enterprises, Australia. \\ ${ }^{4}$ Consultant Austeur Enterprises, Australia. \\ Correspondence: Gary MacLennan, Consultant Austeur Enterprises, Australia.
}

Received: September 1, 2016

doi:10.11114/ijsss.v4i11.1922
Accepted: September 13, 2016

URL: http://dx.doi.org/10.11114/ijsss.v4i11.1922

\begin{abstract}
The purpose of this paper is to give a conceptual account of an approach which seeks to advance the professionalization of the Aboriginal Education Workers (AEW) and Teacher Aides (TA) in remote communities in Australia. We set out the current situation where the training and support offered to the AEW/TA is such that their potential to make a contribution to the education of Indigenous children is either underdeveloped or inaccessible. We then describe the roll out of a specifically designed set of modules that form part of a novel approach to the professional development of the AEW/TA, and go on to analyse the lessons that may be learned from early phases of the project. Our analysis draws upon Critical Realist theory (Bhaskar, 2016), the work of the media theorist Hans Magnus Enzensberger and Charles Leadbeater's (2014) use of the concept of a cultural commons, and the emerging literature on frugal and inclusive innovation (George, McGahan, \& Prabhu, 2012; Radjou, Prabhu, \& Ahuja, 2012; Tiwari \& Herstatt, 2012) .
\end{abstract}

Keywords: aboriginal education worker, absence, alienation, cultural commons, emancipation, enfolded, frugal innovation, inclusive innovation, technology, meta-reality

\section{Introduction}

The parlous state of Indigenous education in Australia has been frequently commented on. ${ }^{1}$ The recent Closing the Gap Report indicated that, although some progress had been made, there was still much to do before the gap between the educational achievements of Indigenous and non-Indigenous students could be closed. ${ }^{2}$ It was against this background that our team, led by Ian Mackie, ${ }^{3}$ proposed a project that addressed the role of the Aboriginal Education Worker (AEW) or Teacher's Aide (TA).

Although there are some exceptions, it is standard practice for most schools in Indigenous communities to employ AEW's. The value of them being from the local community, and knowing the children and their families is clearly recognized by the educational system in which they work. They speak the child's language, or dialect, and can communicate with a greater ease and effectiveness with the students than many of the classroom teachers. Additionally, if done well, AEWs act as a form of "expert cultural mediator" between the students and the classroom teachers, helping each to better understand the viewpoint, and therefore motivations of the other. Ideally, this ability to bridge cultural and communication gaps between home and the school helps to make the children feel more at ease in the school setting, and better able to focus on their learning. In addition, and perhaps most importantly, because they live within the

\footnotetext{
${ }^{1}$ Smallwood (2015) has addressed Indigenous disadvantage from the standpoint of the absence of human rights. We are in substantial agreement with her approach

${ }^{2}$ (Prime Minister, 2016) - There is a series of annual reports on the Gap made to Parliament by the Prime Minister. In the mass media, the release dates of these reports have evolved into annual exhibitions of gloom and doom and failure to recognize any progress in some areas

3 Austeur Enterprises is a private Educational Consulting firm, with over 10 years' experience, specializing in empowering school leaders and staff to reform the heteronomous culture of their schools, and empower their students
} 
community themselves, AEWs, offer a mich greater chance for continuity of relationships with the students over time, amidst the ceaseless turnover of non-Indigenous teaching staff through remote schools.

\section{The Current Situation in Indigenous Schools}

There are, undoubtedly, many examples of AEW's who are doing outstanding work in partnership with teachers. Nonetheless, a conversation is needed around whether they are sufficiently enabled to perform their role to an effective professional standard, and what may be done to better facilitate this. In some cases, inadequate personal literacy and numeracy, and at times, low motivational levels mean that too often the Indigenous teacher aide is unable to contribute fully to the education of their community's children. Principals provide anecdotal reports of situations where an AEW attends school in an irregular fashion, and is positioned passively at the back of the classroom, to occasionally "growl" the children whose behaviour has become disruptive.

It is also reported by Principals that some teaching staff are unaware of how to most effectively utilize the AEW within their classroom, as they are not completely sure of where their authority ends, and that of the AEW begins. Unfortunately, there have even been some examples where AEWs were not seen by the school teaching staff as co-workers in a common endeavour. In one instance, a remote Queensland community until very recently did not even permit AEWs to enter the staff room.

The general picture then, is one ranging from discrimination against AEWs at worst, through to at best an ad hoc approach to their professional development. Nonetheless, it is important, as we have indicated, to recognize and applaud the excellent work that has been and is being pursued in some schools.

We see our current endeavour, which is still in the process of being implemented, as a departure from the currently dominant "individual skill development" paradigm of AEW training, which would be described by the critical realist philosopher Roy Bhaskar as a Weberian stereotype, that emphasises 'voluntarism', a view which sees social objects as the result of intentional individual human behaviour. This model of interaction between social structures and human agency is criticised by Bhaskar as having "actions, but no conditions" (Bhaskar, 1998, p. 37).

In contrast, and in line with Bhaskar's critical realism, we favour a turn towards a collective team-building and a motivational paradigm, which eschews Weber's voluntarism, and instead opts for Bhaskar's "transformational model of social activity", where both the actions of individuals and the wider structures of society are simultaneously irreducible to one another, and dependent upon one another for their action and perpetuation (Shipway, 2011). We see this understanding of the interaction between individuals and educational institutions as essential to the process of self-realisation and the releasing of what is already implicated or enfolded within the AEW and indeed the entire Indigenous people of Australia. ${ }^{5}$.

In 2013 Austeur Enterprises, led by Ian Mackie, did a major study of the range of programs employed to improve Teacher Aide contribution across the educational systems of. Although the model of individual advancement and skill acquisition was by far the most-used approach, its outcomes in terms of student engagement and participation in the life of the school were significantly inferior to the comparatively few models of whole-school re-culturing and explicit team building. The exceptions to the general pattern of under-utilisation of the potential of the Indigenous staff, were the approach pioneered at Cherbourg by Dr Chris Sarra (Sarra, 2005, 2011, 2012)and the micro skills video project piloted in six remote communities by the consultants at Austeur Enterprises in 2014 ..

It was against this background that we designed a suite of 14 modules, each designed to convey and reinforce a key message (Appendix A). The modules ranged in intent from conceptual and motivational, through to practical and detailed suggestions on how to tackle literacy and numeracy consistently and effectively in class. The central innovation of this program was that the modules were supported by set of powerpoint files that asked the AEWs and their partnering teachers to embed pictures and video clips that they themselves took of their work in the school and their community. These original, co-produced media, were then categorised by the participants according to the 14 key empowering messages contained in the module workbook. This was a relatively simple, yet highly interactive and collaborative use of technology, and its power was derived from the fact that it assumed the AEWs would work alongside the classroom teachers as colleagues to collect, and then critically analyse their own everyday actions within the school community.

\footnotetext{
4 To "growl" someone is to speak harshly to them, with an underlying connotation that there exists some level of underlying threat of unspecified consequences.

${ }^{5}$ We are strongly of the view that an approach to Indigenous matters should proceed from a meta-realist standpoint. That is, it should begin with a full consciousness of the strengths within Aboriginal People. For us that means a meta-Reality approach (Mackie \& MacLennan, 2015).
} 
The enthusiasm, comradery, and reflexivity this simple program has aroused caught us by surprise, and we have since been asked by some seasoned observers of the Indigenous educational scene to offer an explanation for why such motivation was generated between the AEWs and the teaching staff.

\section{Community development in the Anangu Schools}

Our first step in the process of analysing the success of the project is to turn to community development theory (CD) (Gordon \& Frame, 1995; Tan, 2009). Although, community development is a somewhat subjective term (Ife, 2009), without belabouring the point too much, it is our contention that the AEW Project may usefully be seen as a Community Development Enterprise in that the focus is on 'the centrality of oppressed people in the process of overcoming externally imposed social problems (Tan, 2009, p.5). Each of the schools in the sample employs Anangu people as AEWs from the local community. The workers share commonalities of culture, language and social purpose. There are strong clan and familial links between many of the AEW's and the children in the school. With these powerful connections in mind, we may examine the outcomes of the project in terms of Community Development and Capacity Building.

Our Project team approached the task of providing a training package for the AEW's with some preconceptions, and it was important that our own preconceptions were explicitly acknowledged and tested at this early stage, as opposed to being allowed to lie embedded below the surface of our conscious perception.Some of these preconceptions included the assumptions that many local AEWs had:

- low literacy skills,

- technology poor environments,

- geographic and systemic isolation, and were

- disengaged workers.

From the beginning of the first two-day workshop in Alice Springs, each of these preconceptions were challenged and largely disproven.

There were over forty AEWs with which our team were in contact, and while it was true that a small number did exhibit some deficits in Standard English, the majority had no problem reading and understanding text when the context of that text was made clear. Most possessed a sound working literacy and numeracy capacity that enabled them to function effectively within and outside of the context of their school and community. All of the AEW's were highly effective communicators in their home language or languages both verbal and written.

All of the Anangu schools visited by the team were technologically rich environments. Laptop computers, desktop PC, tablets, smart boards, televisions and teleconferencing equipment were all readily available. Most of the AEW's used the available technology regularly, and had free access to the equipment. The one deficit in all schools with the exception of one was mobile phone access. This is limiting in terms of their personal communication and for the project, eliminating a ready and useful video capture device from their repertoire.

The Anangu Lands are geographically isolated. However there is reasonable year round road access, although it is more suitable for four-wheel drive vehicle. However, there is nonetheless a local culture of proud use of relatively cheap, semi-disposable conventional vehicles.

The phenomenon of the "disengaged worker" is perhaps the most relevant to this discussion of the Community Development elements of the project. In previous visits to the sample schools, the disengagement of the Aboriginal workers in their daily tasks was clearly evident. Boredom and disinterest were the common traits for a large proportion of the sample. Of course, there were some striking exceptions.

Given the socio cultural context of the schools, the availability of information and communication technology and relatively high literacy levels of the workers, our preconceived ideas were obviously not as constraining as we had originally thought. So what then, might explain the disengaged behaviour of workers? If we look at Arnstein's (1969) Ladder of Citizen Participation (Table 1) where would the citizens of the Anangu schools sit? What control do they have over their environment, their work, their conditions, the processes and products of the school? Admittedly, it would be inaccurate to say that each of the sample schools was identical. Each has its own unique character and set of advantages and problems. Each of the principals has their own professional skill set, approach to the job and level of experience. Nevertheless, we are convinced that there do exist some useful generalizable but tentative conclusions to be reached from the project even at this stage. 
Table 1. Ladder of Citizen Participation (Arnstein, 1969)

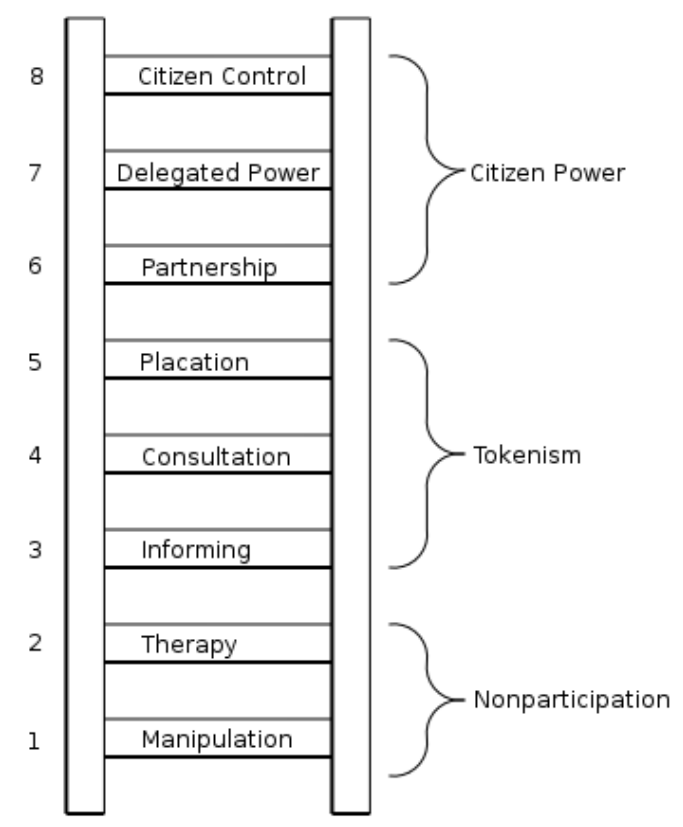

In most schools, and this is based only on the observation of the team members and from conversations with AEW's and the mostly non-Indigenous teaching staff, it would seem that for the most part the AEW's have not risen much above the tokenistic levels of participation. Thus, their lives are marked by little actual power over their own circumstances.

This is hardly surprising given that they and the others members of their communities could be described as members of the precariat -denizens of Precaria, that imaginary country whose occupants lead lives of marginalisation and uncertainty (Standing, 2014a, 2014b) . ${ }^{6}$ Although the concepts of Precaria and a Precariat are not without their critics (Breman, 2013), the data would suggest that the lives of the Indigenous occupants of the former reserves are marked by those qualities that have been described as the hall mark of the inhabitants of Precaria, that is, the Four A's - 'anger, anomie, anxiety, alienation'. ${ }^{7}$ It is the latter concept that we concentrate on below.

Although we do not wish to make any extravagant or triumphalist claims for what we have achieved, at the same time we wish to avoid lending any purchase to feelings of despair. Indeed, the reaction from the AEW's to what the project team believed were relatively low level technological feats was startling. Frankly, the team was unprepared for the intensity of enthusiasm and deep engagement the AEW's displayed. Of course there are many possible explanations. However, from a CD view point it is not difficult to surmise that the AEW's experienced a degree of power and control previously unknown to them. They immediately saw the potential to enter into a more collegial and equal form of partnership with the non-Indigenous staff.

\section{The Project in Action: Return of the Self}

At Fregon SS, the AEW leader, Auntie Mary [not real name] insisted on being in control of the format for the first slide of Module One. She commented that the project was very important for her people and they had to get it right. She urged strongly that the slides reflect the place of the AEW in the community and in the school, and the school in the community. She explained it was important for her team as Indigenous people. So the generic title was changed to Anangu Fregon School AEW Project. This brief moment encapsulated for us key features of the project. Firstly, we had involvement based on an understanding that what was happening was important. Secondly, we had the assumption that what an Indigenous leader said would be listened to with respect. Thirdly, there was confidence that her wishes would be acted on at once.

As part of the making of a video and powerpoint for Module One, Auntie Mary's group went away and came back with a series of key statements about why their work was important. They wanted these filmed. The statements were

Why is this work important?

\footnotetext{
6 Standing (2014a); (Standing, 2014b)

${ }^{7}$ Breman (2013, p.133).
} 
- Keeping our language and culture strong

- Sharing our way, our language with the students and teacher

- Working together and building a strong relationship with our students and teacher

- Building our children's future in our schools

- As our children grow up they are the future community leaders

- We are Important to our schools because we are role models for our children

- We are Anangu people and we are first teachers for our children and culture.

The filming was a joyous process and there was a final flourish of clenched fists at the strong affirmation of their collective identity and purpose in the last statement. We were struck here by the playfulness of the participants. There was much friendly laughter and good hearted teasing as the images of one another came on the screen. Clearly, this was a source of collective pleasure to them and we reflected on the relevance of Enzensberger's emphasis on the 'emancipatory possibilities of populist cultural practices' ${ }^{8}$

At Ernabella SS, Auntie Joan [not real name] insisted on a change to the slide entitled The school needs me. She argued strongly for that to be changed to The Schools need us. She felt that what they were doing at Ernabella was relevant to all the schools in the Anangu Lands and to all of her people.

For us what was happening was a move away from the possessive individualistic ego towards the social self. MacPherson has described well the characteristics of the possessive individualism that liberalism promotes, especially in its neoliberal guise. ${ }^{9}$ But there are constraints on the promotion of the egoistic individual and these constraints are rooted in the sociability of human nature and the impulse to share that enables the poor and the marginalised to survive. ${ }^{10}$ For Bhaskar, the self is intrinsically social, and is linked to our ground states of love and solidarity. The ego is false and individualistic and seeks to deny our essential social-interdependence. ${ }^{11}$ A contemporary instance of this is the Scorsese film The Wolf of Wall Street.

In a discussion with a white teacher of his experiences of the preliminary workshops held in Alice Springs at Amata, the following points emerged. He made clear that his expectations of the project were that it would follow the normal pattern of gearing up the participants for the individual acquisition of certification. Instead, he found the emphasis not on individual acquisition of certificates but rather on the building of a collective endeavour to boost the welfare of the people of the Anangu Lands. He also commented on his role in the translating the powerpoints into Pitjantjatjara language. He found the experience disempowering because of his absence of fluency in Pitjantjatjara. He noted that the AEW, by contrast, found the experience empowering. This was a reversal of the normal experience of the Anangu people of western education, and also a reversal of the power relationship that normally characterised his relationship with the AEW. For him, as a teacher, the experience was enlightening, challenging and liberating.

Our reflection was that this shift in power echoed Marx's remark in the third thesis on Feuerbach that the educator must be educated, and it realised in a practical way in Bhaskar's fine description of the ideal of the teacher-student relationship. $^{12}$

**Perhaps think about putting an excerpt of this quote in block format here?**

Hartwig in his interviews with Bhaskar talked of the 'teacher-student relationship as a model for the kind of relationships that must supersede the master slave order'. ${ }^{13}$ It was our feeling that as we moved to the margins of the room and the AEW's took centre stage that we had come close to seeing in action what Hartwig described. Certainly it was our impression that the AEW's were in the process of achieving something of rare importance. To understand this process we turn now to the concept of alienation and in particular to Bhaskar's use of the term.

\subsection{Alienation}

Schact in his discussion of alienation likens the use of the term to a speaker tapping a glass to get attention, as the word

\footnotetext{
${ }^{8}$ King $(2007$, p.16).***I think we have a mix of in-text citation, and citation by footnotes throughout the paper, perhaps best to choose one. By footnote?

9 Macpherson (1977)

${ }^{10}$ Bhaskar (2002)

11 We think that the description of the origins and main outlines of possessive individualism by MacPherson (1977) is still both insightful and relevant for an understanding of the dynamics of the neoliberal age (1973-2008).

12 Bhaskar (2000, p.103)

13 Bhaskar and Hartwig (2010, p.154)
} 
has been 'so loosely applied that it no longer means anything at all'. ${ }^{14}$ We hope to avoid a lax use of the term by referring specifically to Bhaskar's use. Firstly though, it is worthwhile to acknowledge that there are two principal approaches to alienation. The first of these regards alienation as an essential aspect of the human condition. I am, therefore I am alienated. Why should this be so? Neoplatonism talked of an original unity which is broken when the soul sees itself in the mirror of Dionysos. ${ }^{15}$ The soul is somehow tempted to take flesh. The original unity will be restored after death.

Alienation also appears in the early Christian texts. Saint Paul writes, 'Remember that you were without Christ, being aliens from the commonwealth of Israel, and strangers from the covenant of promise, having no hope, and without God in the world, 16

The feeling that there is something missing in humanity was also expressed in the famous statement of Saint Augustine - "Thou madest us for Thyself, and our heart is restless, until it repose in Thee"17

The problem with this approach to alienation is that it cannot be cured short of a dash through the Pearly Gates. Nevertheless, it does capture something of the feeling of separateness which plagues humanity, and which seemingly can only be overcome in the experience of ecstatic communion, as in the famous Caliban speech from The Tempest.

Be not afeard. The isle is full of noises,

Sounds, and sweet airs that give delight and hurt not,

Sometimes a thousand twangling instruments,

Will hum about mine ears, and sometime voices,

That, if I then had waked after long sleep,

Will make me sleep again. And then, in dreaming,

The clouds me thought would open and show riches,

Ready to drop upon me, that when I waked,

I cried to dream again. ${ }^{18}$

\subsection{Bhaskar on Alienation}

By contrast with the notion that alienation is an essential and in-eliminable existential aspect of being human, there is the more materialistic approach which sees alienation as a geo-historical phenomenon and therefore capable of being reversed. ${ }^{19}$ This approach to alienation can be traced back to Marx's 1844 manuscripts. There Marx wrote:

First, the fact that labor is external to the worker, i.e., it does not belong to his intrinsic nature; that in his work, therefore, he does not affirm himself but denies himself, does not feel content but unhappy, does not develop freely his physical and mental energy but mortifies his body and ruins his mind. The worker therefore only feels himself outside his work, and in his work feels outside himself. He feels at home when he is not working, and when he is working he does not feel at home. His labor is therefore not voluntary, but coerced; it is forced labor. It is therefore not the satisfaction of a need; it is merely a means to satisfy needs external to it. Its alien character emerges clearly in the fact that as soon as no physical or other compulsion exists, labor is shunned like the plague. ${ }^{20}$

Building on Marx's work, Bhaskar defines alienation as "the condition of being separated, split off or estranged from what is essential and intrinsic to a being's nature or identity". ${ }^{21}$. He describes this process as belonging to the third level of his dialectic, that of totality. ${ }^{22}$ So, for Bhaskar, alienation involves being split off from what one produces,

${ }^{14}$ Schacht (1972, p.237)

15 (Bull, 2001; Seaford, 1998)

16 (St Paul as cited in Mészáros, 1978, p.28)

17 Saint Augustine (401/2013, p.1)

18 Shakespeare (1611).

19 In a sideswipe at Žižek, Bhaskar writes 'Far from being primordial with the development of language and the symbolic order, and so irremediable, as a fashionable Lacano-Hegelian metanarrative has it, alienation is geo-historical and reversible' (Bhaskar, 2016, p.56)

20 (Marx, 1844/1959, p.30)

21 (Bhaskar, 2016, p.70)

22 The Bhaskarian dialectic was first unfurled in Dialectic the Pulse of Freedom. Bhaskar's levels of rationality outline the types of knowledge which are necessary for the possibility of emancipation. These levels of rationality first appear in SRHE (Scientific Realism and Human Emancipation) before the dialecticalisation of CR. With the development of DCR, some 'juggling' took place to make room for dialectical rationality in the category of emancipatory reason (as identified by * in Table 2). 
being spilt off from oneself, from nature, from institutions and other human beings, that is the four levels of social being. ${ }^{23}$ As well, for Bhaskar alienation was tied to the process of the development of modernity and 'to the rise of earlier forms of master-slave-type societies. ${ }^{24}$

Interestingly, an early statement of an aspect of this splitting process occurs in Emerson's address in 1838 at Cambridge. There he said:

The state of society is one in which the members have suffered amputation from the trunk and strut about so many walking monsters - a neck, a stomach, an elbow, but never a man.

Man is thus metamorphosed into a thing, into many things....The tradesman scarcely ever gives an ideal worth to his work, but is ridden by the routine of his craft and the soul is subject to dollars. The priest becomes a form; the attorney, a statute-book; the mechanic, a machine; the sailor, a rope of a ship. ${ }^{25}$

The solution to alienation is to engage in retotalization, that is, to end the splitting process. In Bhaskar's seminal Dialectic: the Pulse of Freedom one of the paths to this solution is through 'collective embodied intentional agency'.

A possible explanation for the success of this project is that, as we have seen, it facilitates the growth of the social self and replaces the ego. Within the AEW project the participant goes from the role of the isolated passive receiver who is intrinsically alienated, to becoming a producer who is organically linked to their community. We will have more to say on this when we come to discuss the role of technology.

\subsection{The Media and the Process of Emancipation}

Hans Magnus Enzensberger in his prescient meditations for a theory of the media makes the point that every element of the media in theory allows for production as well as reception. ${ }^{26}$ The digital age has seen Enzensberger's point come to full realization. Our emphasis on using technology, which was freely available and in insisting on showing how it could be used, enabled the AEW's to move from reception to production. If we examine Enzensberger's profiling of emancipatory media practice in Table 2 below we can see that our practice belongs to the emancipatory axis.

Table 2. The Dialecticalisation of Bhaskar's Rationality

\begin{tabular}{|c|c|c|c|c|}
\hline \multirow[t]{2}{*}{ Type of reason } & \multicolumn{2}{|l|}{$C R$} & \multicolumn{2}{|l|}{$D C R$} \\
\hline & Level & Name & Level & Name \\
\hline \multirow{2}{*}{$\begin{array}{l}\text { Instrumental } \\
\text { reason }\end{array}$} & I & Technical rationality & I & Instrumental rationality \\
\hline & II & $\begin{array}{c}\text { Contextually situated } \\
\text { instrumental rationality }\end{array}$ & II & Critical rationality \\
\hline \multirow[t]{2}{*}{ Critical reason } & III & Practical rationality & III & $\begin{array}{c}\text { Explanatory critical } \\
\text { rationality }\end{array}$ \\
\hline & IV & $\begin{array}{c}\text { Explanatory critical } \\
\text { rationality }\end{array}$ & IV & $\begin{array}{c}\text { Depth explanatory critical } \\
\text { rationality }\end{array}$ \\
\hline \multirow[t]{2}{*}{$\begin{array}{c}\text { Emancipatory } \\
\text { reason }\end{array}$} & V & $\begin{array}{l}\text { Depth-explanatory critical } \\
\text { rationality }\end{array}$ & V & $\begin{array}{c}\text { Totalising depth } \\
\text { explanatory critical } \\
\text { rationality }\end{array}$ \\
\hline & VI & Depth-rationality & VI & *Dialectical rationality \\
\hline $\begin{array}{c}\text { Historical } \\
\text { reason }\end{array}$ & VII & Historical rationality & VII & Geo-historical rationality \\
\hline
\end{tabular}

\begin{tabular}{|l|l|}
\hline Repressive use of media & Emancipatory use of media \\
\hline Centrally controlled program & Decentralised program \\
\hline One transmitter, many receivers & Each receiver a potential transmitter \\
\hline Immobilisation of isolated individuals & Mobilisation of the masses \\
\hline Passive consumer behaviour & Interaction of those involved, feedback \\
\hline Depoliticisation & A political learning process \\
\hline Production by specialists & Collective production \\
\hline Control by property owners or bureaucracy & Social control by self-organization \\
\hline
\end{tabular}

\footnotetext{
${ }^{23}$ Bhaskar (2008)

24 (Bhaskar, 2016, p.164)

25 Emerson (1900, p.565)

${ }^{26}$ Enzensberger (1976)
} 
Table $2{ }^{27}$ Source (Enzensberger, 1976, p.38)

By moving from the passive consumption of information and the guided low-level use of technology to the active production of their own knowledge products, the AEW's immediately saw the potential power they could bring to the education process. Seeing their own faces, those of their friends and family being reproduced in high quality education products and experiencing competence in the process unlocked a latent potential.

It must be recognised that the rungs on Arnstein's ladder (Table 1) can be gaping chasms almost too wide for the individual to contemplate and far too daunting for an individual to attempt to broach. It takes a community to build a community and it takes the good will of a bureaucracy to relinquish power; to reach down and allow those on the lower rungs to rise up.

Viewed in Community Development terms, the products of this project are not the artefacts attached to the modules, the power point presentations, the workbooks, or even the meta messages. The real product is the process of meaningful development and genuine empowerment of the AEW. We would also point out that we were anxious that our project would contribute to the development of a cultural commons, not only in the Anangu Lands but throughout Australia. Accordingly, we have made all material publicly available on our web sites. ${ }^{28}$ We think of the meta-statements as the site of meanings, and we agree with Sherman's statement that 'Meanings, unlike pastures and fisheries, are strengthened rather than depleted with use'. ${ }^{29}$

\subsection{The New Technology; Frugal and Inclusive Innovation}

There is a sense that the technology is owned and used by them. Leadbeater is a thought leader in this domain. At times so great is his enthusiasm that it leads him to endorse approaches such as Sugata Mitra's Hole in the Wall approach to education. ${ }^{30}$ Seemingly, all that is necessary is to get a wall, stick a computer in it and emancipation will follow. Clark (2013) has expressed doubts about Mitra's claims, but as we pointed out above there is a kernel of truth in that the new technology enables receivers to become producers and broad casters and that is potentially liberating. ${ }^{31}$ However, even before the technology itself can play a liberating role, there first must be clearly established the expectation that the AEWs themselves were both given permission by the previously dominant social powers (the school leadership), and were identified as capable to take the lead in using the technology in the first place. Additionally, the social media provides platforms that did not exist before. This changes appear to be at the heart of Leadbeater's Utopian optimism. ${ }^{32}$

We would also argue that our project could be understood in terms of the new phenomena of frugal and inclusive innovation. ${ }^{33}$ The definition given of frugal innovation is 'meeting the desired objective with a good-enough, economical means ${ }^{34}$ Inclusive innovation is defined as the 'Development and implementation of new ideas which aspire to create opportunities that enhance social and economic wellbeing for disenfranchised members of society' ${ }^{35}$ It is our tentative contention that our project met both sets of criteria. The technology was kept to as simple as possible, as were the production values and techniques. Our aim was to enable marginalised members of our society to position themselves as agents within what can be a large bureaucratic and impersonal force.

\section{Literacy Old and New}

There is as well the fact that the new literacy is outside the control of the mandarin caste. The old literacy seems deeply connected to the monopolisation of power. Ong relates the story of the resistance of educated Koreans, who had mastered the complex chirographic system of writing Korean, towards the introduction of an alphabetic system which would make literacy more widespread. ${ }^{36}$ The elite were very conscious that much of their power depended on the monopoly of the writing system As Enzensberger also notes the example of spelling shows that although spelling mistakes may be "completely immaterial in terms of communication [ they will be] punished by the social exclusion of the writer'. ${ }^{37}$ Interestingly, research shows that the stigmatizing of non-standard spellers seems to persist into the age of

${ }^{27}$ Enzensberger (1976, p.38)

28 www.nudgeforschools.com;

29 Sherman (2016, p.177)

30 (Leadbeater, 2011; Mitra, 2006; Mitra \& Rana, 2001)

31 (2013)

${ }^{32}$ Leadbeater (2014); (Smith, 2014)

33 (Soni \& Krishnan, 2014)

34 Ibid p.32

35 Ibid p.34

${ }^{36}$ Ong, 1982 pp. $90-91$

37 Enzensberger,1976, p.48 
the social media. ${ }^{38}$

\subsection{Creativity}

So seem to be the lessons at this early stage of the project? We think that the form of the modules, with their clear emancipatory expectations established from the outset, allowed a "space" to emerge which in turn allowed what was enfolded in the people to unfold and shine forth. In other words, we made an explicit decision to "get out of the way" of the intrinsic . enfolded creativity of the AEWs. To some extent, this could characterise us as followers of the philosopher Jean Jacques Rousseau, famous for the statement "man was born free and is everywhere in chains'. 39

There are many things that offer remarkable potential for hope in what happened, but from the point of view of creativity, what is most suggestive for us is that in its epiphanic nature it echoes, some other great moments. We are thinking here of course of Paul on the road to Damascus, and also the philosopher Jean-Jacques Rousseau in 1749 on the road to Vincennes reading of the essay topic set by the Dijon Academy "Has the revival of the arts and sciences done more to corrupt or to purify morals?" Rousseau was to describe what followed in this way:

Suddenly I felt my mind dazzled with a thousand illuminations; crowds of striking ideas came to me at once and with such force and so jumbled together that I was thrown into an inexpressible agitation. I felt my head seized with dizziness as if I were drunk. A violent palpitation overcame me and constricted my chest. Not being able to breathe as I walked, I sank down under one of the trees by the road, and passed half an hour there in such a state of emotion that when I rose I found the whole front of my waistcoat wet with tears that I had not realised I was shedding. How, if I could have written a quarter of what I saw and felt under that tree, how clearly I should have brought to view all the contradictions of the social system, how powerfully I should have laid bare all the abuses of our institutions, how simply I should have demonstrated that man is naturally good, and that it is only through these institutions that men become evil! 40

\section{Conclusion}

It is our observation that many Indigenous people are alienated from Western education. We have followed Bhaskar in defining alienation as being split off from one's true self, from social structures and institutions, and nature - the four planes of social being. We can describe that as the rise of the possessive individual or ego; where the only good is the isolated individual's freedom. Another way to describe this is as the rise of the ego.

However the good news is that underpinning the world of the possessive individual, is the world of our ground states and of our human natures. We are social people and we are people of solidarity, love and compassion. These are spiritual values and it was a source of joy to see these in action in the Anangu Lands. ${ }^{41}$

When we achieve an end to alienation the ego makes way for the self. The self is intrinsically social and arises from our ground states.

Accordingly, we think that what has been happening in this project is that we have allowed the non-alienated self to emerge. The AEW make collective affirming statements. They display their language and talk about their people. We wrote The School needs me. They get into an animated discussion and an elder insists that it be changed to All the schools need us. They say the change is necessary because they speak for all the Anangu people and they cannot be divided. They translate the English into Pitjantjatjara because that is their language and is part of them. They chant 'We are the Anangu people and we are the first teachers of our children' and they clench their fists in defiant affirmation.

It is our hope that this spirit of the defiant affirmation of a positive identity continues and grows, and we feel privileged to have witnessed something of its emergence.

\section{Acknowledgments}

We would like to express our gratitude to the reviewers for their thoughtful and supportive comments and the editorial assistant, James Young, for the invitation to submit a paper. Our sincere thanks go to Senior Education Department Staff Paul Newman and Mark Ames and the school Principals Erin McQuade and Ngaire Benfell who organised and supported our trip. We would also like to acknowledge the courage and the hospitality of the people of the Anangu Lands and

\footnotetext{
38 Boland 2016

39 Rousseau (1762/1968, p.49)

40 (Rousseau as cited in Hall, 1973: 12-3)

${ }^{41}$ Now a note on spirituality: this has been colonised by the major religions, but one can be spiritual without being religious. We think traditional Australian spirituality is based around sympathy for the underdog, solidarity, and a fair go for the battler. It seems to us that Indigenous spirituality, if we leave to one side Indigenous religion, is tied up with respect, generosity and land and culture.
} 
thank them for teaching us so much.

\section{References}

Arnstein, S. R. (1969). A ladder of citizen participation. Journal of the American Institute of Planners, 35(4), 216-224. http://dx.doi.org/10.1080/01944366908977225

Bhaskar, R. (2000). From East to West: Odyssey of a Soul. London: Routledge.

Bhaskar, R. (2002). meta-Reality: The Philosophy of meta-reality. Thousand Oaks: Sage.

Bhaskar, R. (2008). Dialectic: The Pulse of Freedom. London: Routledge.

Bhaskar, R. (2016). Enlightened Common Sense: The Philosophy of Critical Realism. London: Routledge.

Bhaskar, R., \& Hartwig, M. (2010). The Formation of Critical Realism: A Personal Perspective (Ontological Exporations). London: Routledge.

Breman, J. (2013). A Bogus Concept? NLR, 84, 130-138.

Bull, M. (2001). Hate is the New Love. London Review of Books, 23(2), 23-24.

Clark, D. (2013, 4th March). Sugata Mitra: Slum chic? 7 reasons for doubt. Retrieved from http://donaldclarkplanb.blogspot.co.uk/2013/03/sugata-mitra-slum-chic-7-reasons-for.html

Emerson, R. W. (1900). Works of Ralph Waldo Emerson. London: Routledge.

Enzensberger, H. M. (1976). Constituents of a Theory of the Media. In H. M. Enzensbeerger (Ed.), Raids and Reconstructions: Essays on Politics, Crime \& Culture (pp. 20-53). London: Pluto Press.

George, G., McGahan, A., \& Prabhu, J. (2012). Innovation for Inclusive Growth: Towards a Theoretical Framework and a Research Agenda. Journal of Management Studies, 49(4), 661-683. http://dx.doi.org/10.1111/j.1467-6486.2012.01048.x

Gordon, W., \& Frame, R. L. (1995). Real hope in Chicago : The incredible story of how the Gospel is transforming a Chicago neighborhood. Grand Rapids, Michigan: Zondervan Publishing House.

Ife, J. (2009). Human Rights from Below: Achieving Rights Through Community Development. Cambridge: Cambridge University Press.

King, A. (2007). Hans Magnus Enzensberger: Writing, Media, Democracy. Bern: Peter Lang.

Leadbeater, C. (2011). Learning from the Extremes. Paper presented at the Educational Innovation: Charles Leadbeater, Brisbane. Lecture retrieved from

Leadbeater, C. (2014). The Frugal Innovator: Creating Change on a Shoestring Budget London: Palgrave Macmillan.

Mackie, I., \& MacLennan, G. (2015). The Crisis in Indigenous School Attendance in Australia: Towards a MetaRealist Solution Journal of Critical Realism, 14(4), 366-380.

MacPherson, C. B. (1977). The Political theory of Pessessive Indvidualism. Oxford: Oxford University Press.

Marx, K. (1959). Economic \& Philosophic Manuscripts of 1844 https://www.marxists.org/archive/marx/works/download/pdf/Economic-Philosophic-Manuscripts-1844.pdf https://www.marxists.org/archive/marx/works/download/pdf/Economic-Philosophic-Manuscripts-1844.pdf

Mészáros, I. (1978). Marx's theory of alienation (4th ed.). London: Merlin Press.

Mitra, S. (2006). The hole in the wall: self-organising systems in education. New Delhi: Tata-McGraw-Hill Publishing.

Mitra, S., \& Rana, V. (2001). Children and the Internet: Experiments with minimally invasive education in India. British Journal of Educational Technology, 32(2), 221-232.

Prime Minister. (2016). Closing the Gap: Prime Minister's Report 2016. Retrieved from Canberra: http://closingthegap.dpmc.gov.au/

Radjou, N., Prabhu, J., \& Ahuja, S. (2012). Jugaad Innovation: Think Frugal, Be Flexible, Generate Breakthrough Growth. San Francisco: Jossey-Bass.

Rousseau, J. J. (1968). The Social Contract. Harmondsworth Penguin.

Saint, A. (2013). The Confessions of Saint Augustine: Project Gutenberg.

Sarra, C. (2005). Strong and Smart: Reinforcing Aboriginal Perceptions of being Aboriginal at Cherbourg State School. (PHD), Murdoch University. 
Sarra, C. (2011). Strong and smart - towards a pedagogy for emancipation : education for first peoples New York: Routledge.

Sarra, C. (2012). Good Morning, Mr Sarra: My life working for a stronger, smarter future for our children. Brisbane: UQP.

Schacht, R. (1972). Alienation. London: Allen \& Unwin.

Seaford, R. (1998). In the mirror of Dionysos. In S. Blundell \& M. Williamson (Eds.), The Sacred and the Feminine in Ancient Greece. London: Routledge.

Shakespeare, W. (1611). The Tempest.

Sherman, Z. (2016). Primitive Accumulation in the Cultural Commons. Review of Radical Political Economics, 48(1), 176-188. http://dx.doi.org/10.1177/0486613415586993

Smith, N. H. (2014, 16th June). Charles Leadbeater: 'The Frugal Innovator'. Engineering and Technology Magazine, 9.

Soni, P., \& Krishnan, R. T. (2014). Frugal innovation: Aligning theory, practice, and public policy. Journal of Indian Business Research, 6(1), 29-47. http://dx.doi.org/10.1108/JIBR-03-2013-0025

Standing, G. (2014a). A Precariat Charter: From Denizens to Citizens. London: Bloomsbury.

Standing, G. (2014b). The Precariat: The New Dangerous Class (2nd ed.). London: Bloomsbury.

Tan, A. (2009). COMMUNITY DEVELOPMENT THEORY AND PRACTICE: BRIDGING THE DIVIDE BETWEEN 'MICRO' AND 'MACRO' LEVELS OF SOCIAL WORK. Paper presented at the NACSW Convention 2009, Indianapolis, IN. https://www.nacsw.org/Publications/Proceedings2009/TanACommunity.pdf

Tiwari, R., \& Herstatt, C. (2012). Frugal Innovation: A Global Networks' Perspective. Die Unternehmung (Swiss Journal of Business Research and Practice), 66(3), 245-274.

\section{$(\mathrm{cc}) \mathrm{EY}$}

This work is licensed under a Creative Commons Attribution 3.0 License. 